\title{
Fifty years of potato pest control in Poland
}

\section{Pięćdziesiąt lat ochrony ziemniaka przed szkodnikami w Polsce}

\author{
Magdalena Jakubowska ${ }^{1 *}$, Marek Mrówczyński ${ }^{1}$, Anna Tratwal ${ }^{1}$, Tomasz Erlichowski ${ }^{2}$
}

\section{Summary}

The direction of changes that has been currently observed in treatments against Colorado potato beetle shows that new insecticides are safer for humans and the environment by reducing the dosage of active substances from $1200 \mathrm{~g} / \mathrm{ha}$ of organochlorine hydrocarbons to $20-40 \mathrm{~g} / \mathrm{ha}$ in new generations of products such as: pyrethroids, benzoylurea derivatives, neonicotinoids, phenylpyrazoles, carboxamides, organophosphorus, and antronilated diamides. Based on the data from 1977-2006, there was no significant difference in the protection against potato beetle, both in the number of treatments (from 1.2 to 1.5) and in the protected area (from 72 to $82 \%$ ) of the potato crop in Poland. A recent study of the use of plant protection products in potato cultivation (insecticides) conducted in 2012 showed that the number of treatments varies from 1.0 to 2.0 .

Key words: Colorado potato beetle; active substances; number of chemical treatments

\section{Streszczenie}

Kierunek zmian, jaki obserwuje się obecnie w zwalczaniu stonki pokazuje, że nowe insektycydy są bezpieczniejsze dla ludzi i środowiska, poprzez zmniejszenie dawki substancji czynnych, od $1200 \mathrm{~g} /$ ha węglowodorów chloroorganicznych do 20-40 g/ha w nowych generacjach: pyretroidach, pochodnych benzoilomocznika, neonikotynoidach, fenylopirazolach, karboksamidach, fosforoorganicznych i antronilowanych diamidach. Na podstawie danych z lat 1977-2006 stwierdzono, że nie było istotnego zróżnicowania w ochronie przed stonką ziemniaczaną, zarówno w liczbie zabiegów (od 1,2 do 1,5), jak i chronionej powierzchni (od 72 do $82 \%$ ) uprawy ziemniaka w Polsce. Ostatnie badania zużycia środków ochrony roślin w uprawie ziemniaka (insektycydy) przeprowadzone w 2012 roku wykazały liczbę zabiegów od 1,0 do 2,0.

Słowa kluczowe: stonka ziemniaczana; substancje czynne; liczba zabiegów chemicznych

\footnotetext{
${ }^{1}$ Instytut Ochrony Roślin - Państwowy Instytut Badawczy

Władysława Węgorka 20, 60-318 Poznań

${ }^{2}$ Instytut Hodowli i Aklimatyzacji Roślin - Państwowy Instytut Badawczy

Oddział w Boninie

Bonin 3, 76-009 Bonin

*corresponding author: m.jakubowska@iorpib.poznan.pl
} 


\section{Wstęp / Introduction}

Ziemniak jest przykładem gatunku spośród roślin rolniczych, którego skala uprawy, a także wielkość zbiorów od 30-40 lat w całej Europie, w tym również w Polsce, sukcesywnie maleje (Nowacki 2009). Po wstąpieniu Polski do struktur Unii Europejskiej nastąpiło postępujące i szybkie ograniczenie wielkości produkcji i areału ziemniaka w kraju (Rynek ziemniaka 1990-2011). Obecnie w Polsce powierzchnia uprawy ziemniaka, według szacunków Instytutu Hodowli i Aklimatyzacji Roślin - Państwowego Instytutu Badawczego (IHAR - PIB), Głównego Urzędu Statystycznego (GUS) i Instytutu Ekonomiki Rolnictwa i Gospodarki Żywnościowej Państwowego Instytutu Badawczego (IERiGŻ - PIB) wyniosła w roku 2016 około 310 tys. ha (rys. 1). W porównaniu do średniej $\mathrm{z}$ lat 2006-2010 areał uprawy ziemniaka zmniejszył się już prawie o 50\% (Nowacki 2012). Obserwuje się ciągły spadek powierzchni uprawy ziemniaka. Jedną $\mathrm{z}$ głównych przyczyn zmniejszania upraw jest odchodzenie od produkcji ziemniaka na cele paszowe i spadek pogłowia zwierząt, w tym trzody chlewnej. Przeciętne spożycie ziemniaka przez Polaków ulega zmniejszeniu, gdzie jedną z przyczyn należy upatrywać w niskiej konkurencyjności ekonomicznej tego gatunku W porównaniu do innych gatunków roślin rolniczych. Równolegle w uprawie ziemniaka postępuje dywersyfikacja stosowanych technologii produkcji. Ziemniak uprawiany jest w systemach konwencjonalnych oraz w systemach certyfikowanych (integrowanej produkcji i uprawie ekologicznej). Obserwuje się wzrost produkcji i przeznaczenia ziemniaka dla przetwórstwa spożywczego, głównie na frytki i chipsy, co wiąże się z intensywną ochroną przed agrofagami w tych systemach uprawy (Nowacki 2009, 2012).
W Polsce to warunki meteorologiczne (częste anomalie pogodowe) odgrywają najistotniejszą rolę w kształtowaniu plonów ziemniaka. Zarówno nadmiar, jak i niedobór opadów ogranicza prawidłowy rozwój ziemniaka i jakość bulw. Uprawy ziemniaka mogą być atakowane w tych warunkach przez wiele szkodników, powodujących straty w wysokości plonu, jak również jego jakości (Dzwonkowski 2008).

W Polsce od ponad pięćdziesięciu lat najważniejszym szkodnikiem ziemniaka jest stonka ziemniaczana (Leptinotarsa decemlineata Say). Jednak od kilku lat znaczenie tego szkodnika maleje. Wzrasta natomiast znaczenie szkodników glebowych, takich jak: drutowce (Agriotes spp.), pędraki (Scarabidae i Rutelidae) oraz gąsienice rolnic (Noctuidae). Ponadto, obserwuje się lokalne zwiększenie szkodliwości takich polifagów, jak: przędziorek chmielowiec (Tetranychus urticae Koch.), lenie (Bibio spp.), czy mączliki (Trialeurodes vaporariorum Westwood), dotychczas w niewielkim stopniu obserwowane w uprawach ziemniaka. Ze względu na liczne występowanie chorób wirusowych znaczenie $\mathrm{w}$ produkcji ziemniaka mają również mszyce (Aphidoidea), jako ich wektory. Ponadto, w produkcji materiału sadzeniakowego większe znaczenie ma występowanie nicieni, takich jak: mątwik ziemniaczany (Globodera rostochiensis Wollenweber), mątwik agresywny (Globodera pallida Stone) oraz niszczyk ziemniaczek (Ditylenchus destructor L.). Dawniej plantacjom ziemniaka zagrażały także zmieniki (Lygus pratensis L.), pchełka ziemniaczana (Epitrix similaris Genther), wciornastki (Thysanopthera) i skoczek ziemniaczany (Empoascie pteridis Dahlb.) (tab. 1).

Celem opracowania było określenie tendencji zmian jakie zaszły na przestrzeni lat w ochronie ziemniaka przed szkodnikami.

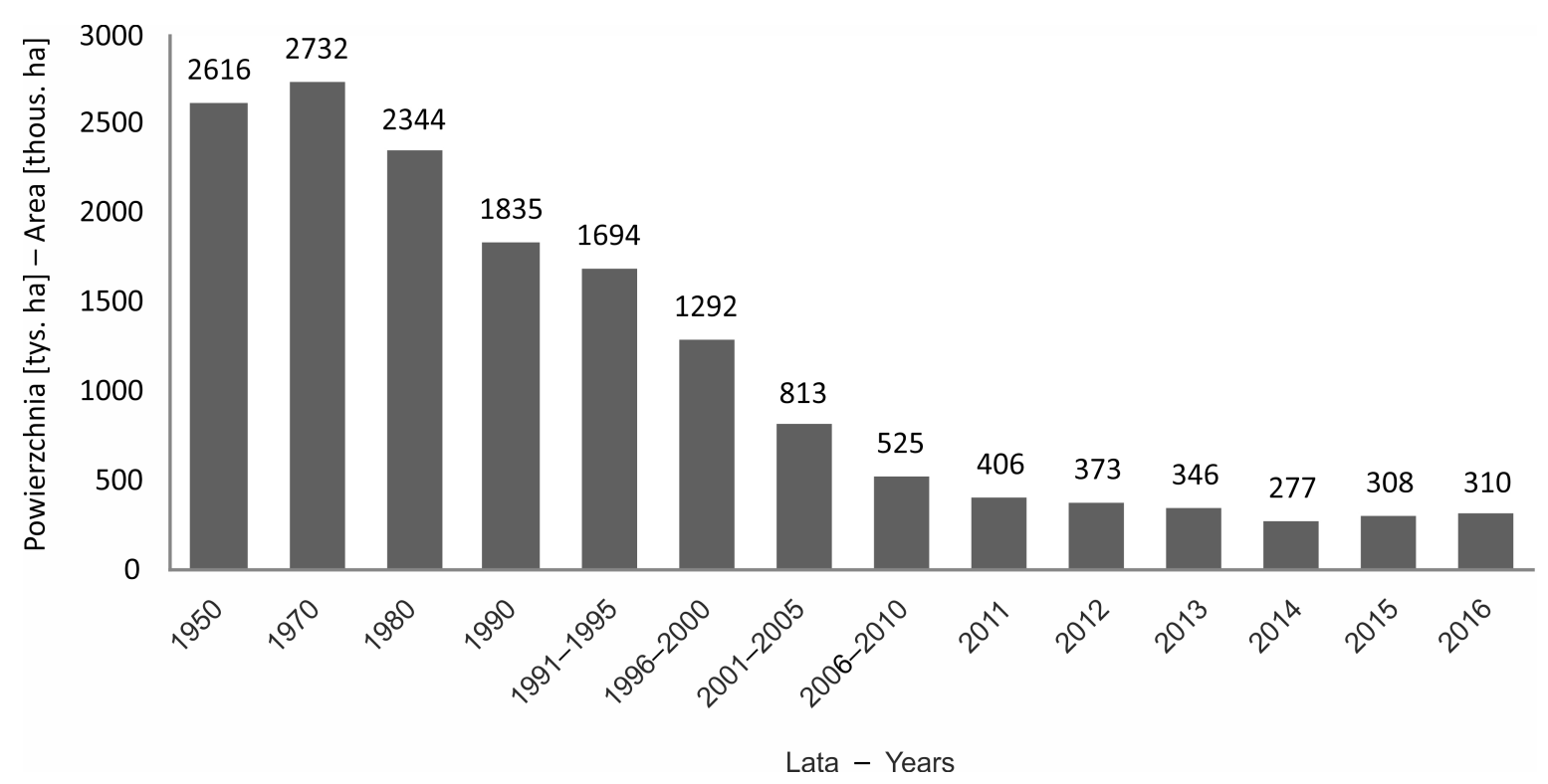

Rys. 1. Powierzchnia uprawy ziemniaka w Polsce na przestrzeni lat [tys. ha]

Fig. 1. The area of potato plantings in Poland over the years [thous. ha] 
Tabela 1. Znaczenie szkodników ziemniaka w Polsce w przeszłości i obecnie

Table 1. The importance of potato pests in Poland in the past and present

\begin{tabular}{|c|c|c|c|c|c|}
\hline \multirow[b]{2}{*}{$\begin{array}{l}\text { Szkodnik } \\
\text { Pest }\end{array}$} & \multirow[b]{2}{*}{$\begin{array}{l}\text { Dawniej } \\
\text { Formerly }\end{array}$} & \multicolumn{4}{|c|}{ Obecnie - Now } \\
\hline & & $\begin{array}{c}\text { sadzeniaki } \\
\text { seed potatoes }\end{array}$ & $\begin{array}{l}\text { frytki i chipsy } \\
\text { french fries } \\
\text { and chips }\end{array}$ & $\begin{array}{l}\text { konsumpcyjne } \\
\text { fresh potatoes }\end{array}$ & $\begin{array}{c}\text { przemysłowe } \\
\text { industrial processing } \\
\text { potatoes }\end{array}$ \\
\hline Drutowce - Wireworms & ++ & +++ & +++ & ++ & + \\
\hline Pędraki - Grubs & ++ & +++ & +++ & ++ & ++ \\
\hline Rolnice - Cutworms & ++ & ++ & +++ & ++ & ++ \\
\hline Mszyce - Aphids & +++ & +++ & ++ & ++ & ++ \\
\hline $\begin{array}{l}\text { Stonka ziemniaczana } \\
\text { Colorado potatoe beetle }\end{array}$ & +++ & ++ & ++ & ++ & ++ \\
\hline Lenie - St. Mark’s fly & + & ++ & +++ & ++ & + \\
\hline Nicienie - Nematodes & ++ & +++ & + & + & + \\
\hline Skoczki - Leafhoppers & + & ++ & + & + & + \\
\hline Zmieniki - Lygus bug & + & + & + & + & + \\
\hline $\begin{array}{l}\text { Pchełki - Potatoe flea beetle } \\
\text { (Epitrix spp.) }\end{array}$ & ++ & ++ & + & + & + \\
\hline Wciornastki - Thrips & ++ & + & + & + & + \\
\hline Zwierzęta łowne - Wild game & ++ & ++ & ++ & ++ & ++ \\
\hline
\end{tabular}

+ szkodnik o małym znaczeniu - low-importance pest

++ szkodnik ważny - important pest

+++ szkodnik bardzo ważny - very important pest

Według Mrówczyńskiego (2017), opracowanie własne - According to Mrówczyński (2017), own elaboration

\section{Materiały i metody I Materials and methods}

W Instytucie Ochrony Roślin - Państwowym Instytucie Badawczym (IOR - PIB) od roku 1964 gromadzone są wyniki obserwacji terenowych, wykonywanych przez pracowników jednostki przy ścisłej współpracy z pracownikami Państwowej Inspekcji Ochrony Roślin i Nasiennictwa (PIORiN), dotyczące nasilenia ważnych chorób i szkodników roślin uprawnych, a w IHAR - PIB, Oddział w Boninie od 1977 roku nasilenia ważniejszych agrofagów w uprawie ziemniaka. Na podstawie prowadzonego monitoringu opracowywana jest ocena stanu fitosanitarnego roślin uprawnych, a wyniki prezentowane są w formie publikacji drukowanych, jak również na specjalnych platformach internetowych $\mathrm{w}$ formie publikacji elektronicznych.

Monitoring stonki ziemniaczanej i innych agrofagów na plantacji ziemniaka opracowano na podstawie danych PIORiN z lat 1977-2016 oraz własnych IOR - PIB. Natomiast zmiany w zalecanych środkach do zwalczania ww. agrofagów, według grup chemicznych, opracowano na podstawie Zaleceń Ochrony Roślin wydawanych przez IOR - PIB w Poznaniu z lat 1960-1996, 2000-2006, 2007-2017 oraz etykiet znajdujących się na stronie internetowej Ministerstwa Rolnictwa i Rozwoju Wsi pod adresem http://www.bip.minrol.gov.pl. Obserwowane przez wielolecia zmiany w ochronie ziemniaka analizowano dekadami: 1961-1970, 1971-1980, 1981-1990, 1991-2000, 2007-2016 oraz latami 2001-2006.

\section{Wyniki i dyskusja / Results and discussion}

Od ponad dziesięciu lat (od 2003 r.) nasilenie stonki ziemniaczanej w Polsce praktycznie nie przekracza średniej wieloletniej wynoszącej 17,3\%. Średnia liczba roślin ziemniaka z objawami żerowania szkodnika w roku 2016 wyniosła w skali kraju 7,6\% (rys. 5). W analizowanym okresie stonkę obserwowano na terenie Polski w różnych terminach. Zróżnicowanie występowania owada na plantacjach ziemniaka zawsze uzależnione jest od odchyleń od przeciętnych warunków atmosferycznych (temperatura, opady) przypadających w sezonie wegetacyjnym ziemniaka. Na podstawie szczegółowej analizy uzyskanych wyników obserwacji terenowych przeprowadzonych w latach 1963-2016 (Pawińska 1995; Pawińska i Mrówczyński 2000; Walczak i wsp. 2006, 2008; Tratwal i wsp. 2016), określono występowanie stonki ziemniaczanej (we wszystkich stadiach rozwojowych), w odniesieniu do wartości średniej wieloletniej. Mniejszą liczebność szkodnika odnotowano w latach 1964-1967, 1969, 1975, 1978-1980, 1985-1989, 1994, 1997-2001 i 2008-2016. Natomiast w sezonach wegetacyjnych 1981-1984, 989-1993, 1995-1996 i 2001-2003 liczebność stonki była wyższa od średniej wieloletniej.

Rozkład poszczególnych faz gradacji pojawiania się owada przedstawiał się w poszczególnych latach w następujący sposób:

- depresja - mała liczebność: 1980, 1985, 1997, 2001, 2012 i 2015;

- progresja - zwiększenie liczebności: 1981-1982, 1986-1991, 1995, 1999, 2001-2002; 
- masowe pojawienie: 1983, 1992-1993, 1995, 2000, 2003;

- regresja - zmniejszenie liczebności: 1978-1979, 1984, 1994, 1996, 2004-2016.

Szczyty gradacyjnego pojawienia stonki miały miejsce w latach 1972-1973, 1983, 1992-1993, 1995-1996 i 2003. Tym samym cykle gradacyjnego pojawienia owada odnotowano po siedmiu, dziesięciu i trzech latach. Wykonane w IOR - PIB w Poznaniu badania, a później prowadzone od ponad 40 lat obserwacje wskazują, że w okresach co 7-10 lat stonka ma tendencje do gradacyjnych pojawów i wtedy też masowo migruje we wszystkich kierunkach (Piekarczyk i wsp. 1984; Sosnowska i wsp. 2009) (rys. 2-5). Śledząc populację szkodnika w latach 1964-1971 można zauważyć stopniowy wzrost znaczenia stonki ziemniaczanej, sięgający powyżej średniej krajowej pod koniec tego okresu. Później nastąpiło załamanie się populacji agrofaga z okresem powolnego wzrostu nasilenia do roku 1980. Do końca lat osiemdziesiątych największe zagrożenie szkodnik stanowił w makroregionach południowo-wschodniej i centralnej Polski. W latach dziewięćdzie- siątych najbardziej zagrożonymi terenami przez stonkę ziemniaczaną były rejony południowo-wschodniej i środkowej Polski (tj. województwa: suwalskie, białostockie, łomżyńskie, chełmskie, zamojskie, przemyskie, rzeszowskie, lubelskie, mazowieckie, siedleckie oraz łódzkie). Najwyższy procent uszkodzonych roślin ziemniaka mieścił się w przedziale od 50 do 75 . W latach 2000-2010 obserwowano szkodnika w rejonach południowo-wschodnich i wschodnich Polski (tj. województwa: podlaskie, podkarpackie, lubelskie, świętokrzyskie, małopolskie) oraz częściowo na terenie województwa warmińsko-mazurskiego i kujawsko-pomorskiego. Procent uszkodzonych roślin ziemniaka przez agrofaga mieścił się $\mathrm{w}$ przedziale od 18 do 65 (Walczak i wsp. 2006, 2008).

Bezpośredniego zagrożenia ziemniaka ze strony mszyc obecnie prawie się nie obserwuje. Zwalczanie tych szkodników jest jednak konieczne, gdyż owady te są wektorami i przenoszą wirusy, z których najważniejsze to PVY, PVM, PVS i PLRV są powodem występowania chorób wirusowych na roślinach. Według Kostiwa (2011), Kostiwa i Robaka (2013), a także na podstawie wieloletnich badań

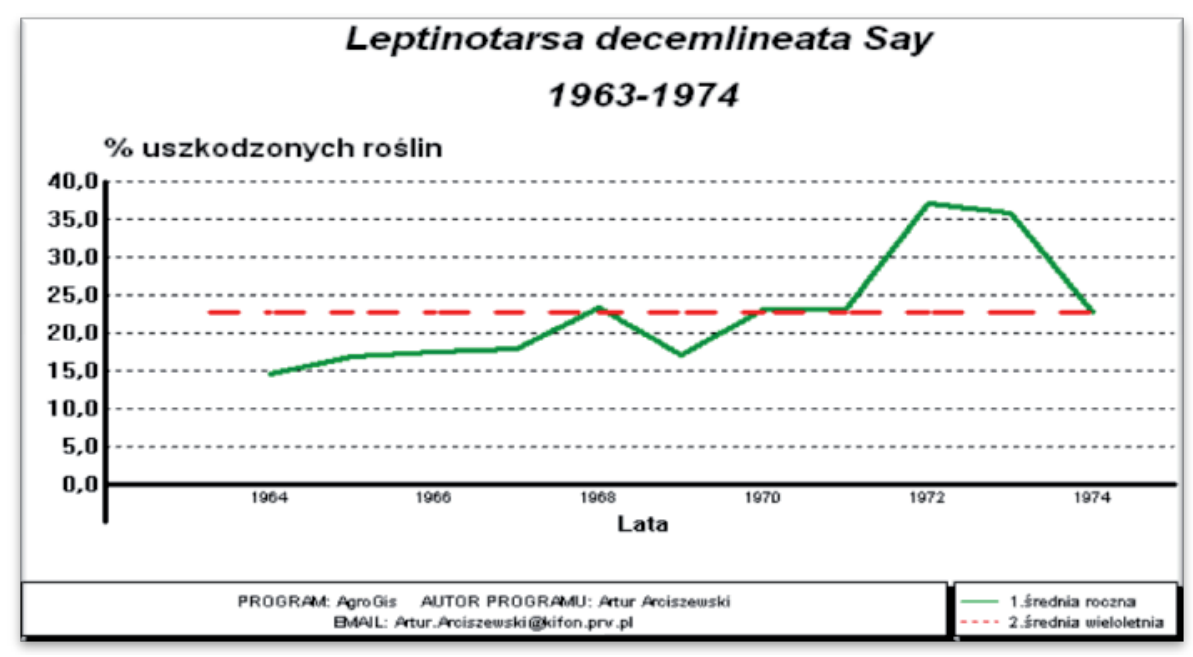

Rys. 2. Średni dla Polski procent uszkodzonych roślin ziemniaka przez stonkę ziemniaczaną w latach 1963-1974

Fig. 2. The average percentage of potato plants damaged by the Colorado potato beetle in Poland in the period of 1963-1974

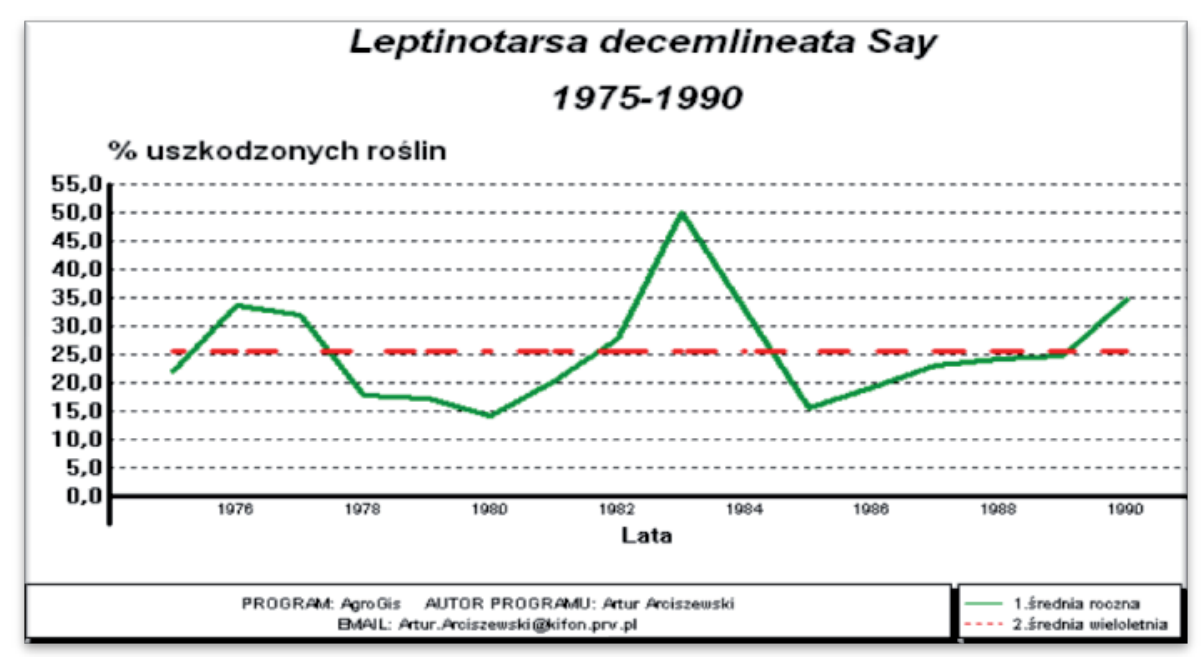

Rys. 3. Średni dla Polski procent uszkodzonych roślin ziemniaka przez stonkę ziemniaczaną w latach 1975-1990

Fig. 3. The average percentage of potato plants damaged by the Colorado potato beetle in Poland in the period of 1975-1990 


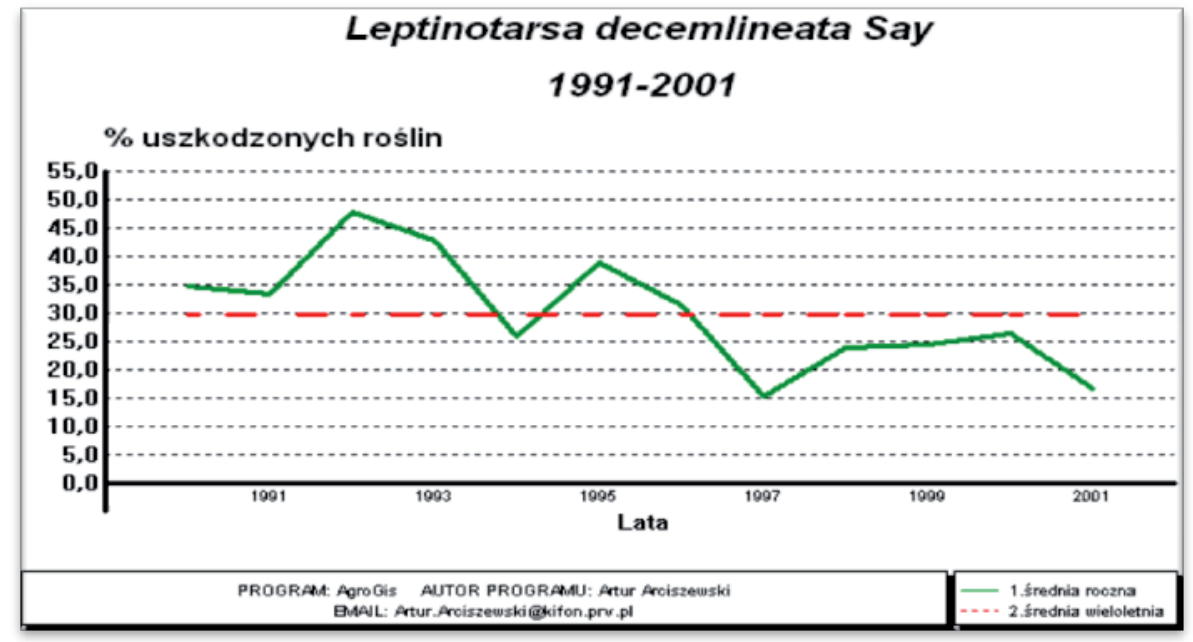

Rys. 4. Średni dla Polski procent uszkodzonych roślin ziemniaka przez stonkę ziemniaczaną w latach 1991-2001

Fig. 4. The average percentage of potato plants damaged by the Colorado potato beetle in Poland in the period of 1991-2001

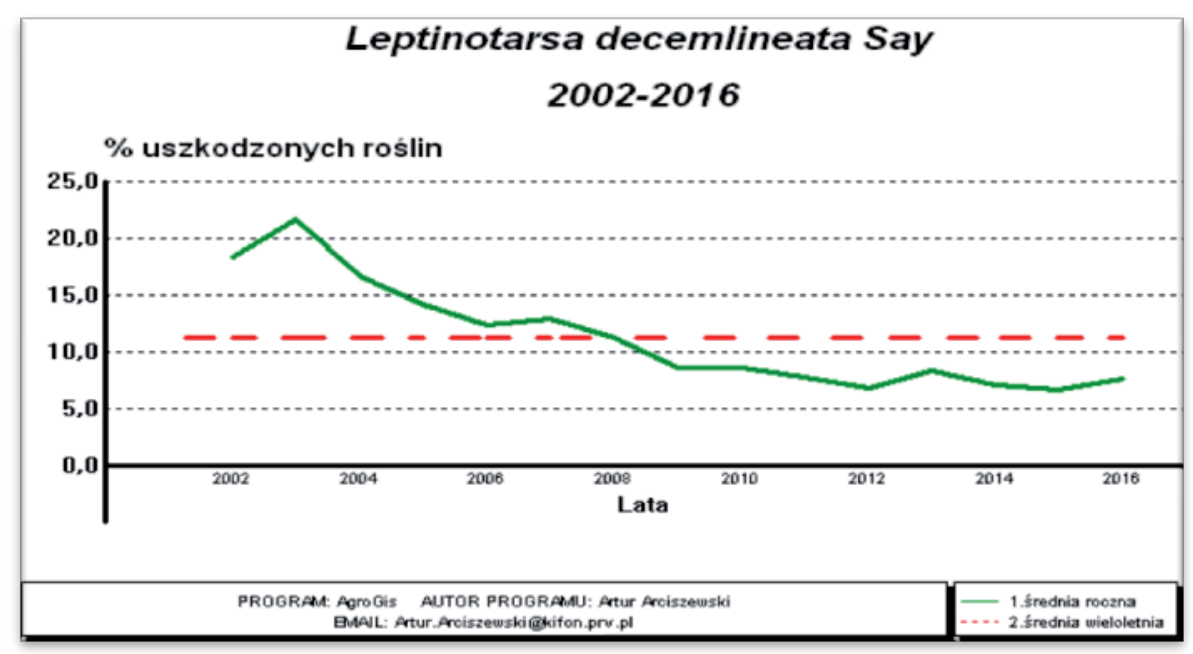

Rys. 5. Średni dla Polski procent uszkodzonych roślin ziemniaka przez stonkę ziemniaczaną w latach 2002-2016

Fig. 5. The average percentage of potato plants damaged by the Colorado potato beetle in Poland in the period of 2002-2016

monitoringowych prowadzonych przez Zespół Pracowni Epidemiologii w Boninie, w kilku miejscowościach w kraju (odłowy do żółtych naczyń) stwierdzono duże zmiany w liczebności gatunków mszyc. $\mathrm{Na}$ przestrzeni wielu ostatnich lat zaobserwowano istotne zmiany zarówno w strukturze gatunkowej, ilościowej, jak i terminie migracji wiosennej mszyc. Zmniejszenie liczebności odnotowały takie gatunki, jak: Myzus persicae Sulz., Aphis nasturtii Kalt. (Kostiw 2011), a Aphis frangulae Kalt. praktycznie zanikła i odnotowuje się sporadycznie tylko pojedyncze osobniki (Kostiw 2007). W okresie 1998-2007 na uprawy ziemniaków nalatywało mniej mszyc, dla których roślina ta jest podstawowym żywicielem, niż jeszcze dekadę wcześniej (1988-1997). Bardzo ważne znaczenie w przenoszeniu głównie PVY mają gatunki mszyc niezwiązane pokarmowo z ziemniakiem tzw. „mszyce nieziemniaczane”. Wśród uskrzydlonych mszyc „nieziemniaczanych" odławianych najczęściej do żółtych szalek najliczniejsze były następujące gatunki: Aphis craccivora (grochodrzewowo-lucernowa), Aphis pomi (jabłoniowa), Cavariella aegopodi (wierzbowo-marchwiowa), Sitobion avenae (zbożowa), Hyperomyzus lactucae (porzeczkowo-mleczowa), Rhopalosiphum insertum (owocowo-zbożowa), Rhopalosiphum padi (czeremchowo-zbożowa) i najliczniejsza - Hayhurstia atriplicis (komosowa). Najliczniej odławianym gatunkiem mszyc „nieziemniaczanych” w latach 2014 i 2015 była mszyca burakowa Aphis fabae (Wróbel i Robak 2015). Ich wiosenny pojaw zawsze wyprzedza terminowo pojaw mszyc typowo ziemniaczanych (Kostiw i Robak 2012; Wróbel i Robak 2015; Erlichowski i Robak 2016). W zależności od uwarunkowań przyrodniczych i gospodarczych naloty wiosenne głównych gatunków mszyc ,ziemniaczanych”, tj. M. persicae i A. nasturtii były odpowiednio 32 dni i 14 dni wcześniejsze niż w okresie 1968-1977 (Kostiw i Robak 2009). W latach 1998-2007 nalatywało na ziemniaki ponad 20 gatunków mszyc niezwiązanych pokarmowo z ziemniakiem, przy czym 10 z nich niekiedy wielokrotnie przewyższało liczebnością mszyce ziemniaczane (Kostiw i Robak 2008, 2009, 2010; Pospieszny i wsp. 2009). Wczesnowiosenne pojawy mszyc uskrzydlonych są bardzo niebezpieczne w produkcji sadzeniaków. Wschodzące 
w maju młode rośliny (szczególnie odmian podatnych na wirusy) są znacznie bardziej podatne na infekcje wirusowe niż rośliny starsze w późniejszym okresie wegetacji, które nabyły w pewnym stopniu odporność związaną z wiekiem. Dlatego tak ważne jest sygnalizowanie pierwszych nalotów (Erlichowski i Robak 2016).

Od kilkunastu lat prowadzone są również w Instytucie w Boninie obserwacje rozwoju populacji mszyc na roślinach w całym okresie wegetacyjnym ziemniaka. Liczenie mszyc bezskrzydłych wykonuje się systematycznie co 10 dni (od ukazania się wschodów do końca sierpnia) na 100 losowo zerwanych liściach z poszczególnych pięter (dolnego, środkowego i górnego) roślin rosnących wokół poletka mszycowego. Analiza wieloletnich wyników pozwala zauważyć pewien trend: najpierw następuje coroczne narastanie liczebności, a następnie gwałtowny spadek populacji. Ostatni taki spadek notowano w 2013 r., kiedy w całym sezonie stwierdzono łącznie tylko 36 osobników bezskrzydłych (Wróbel 2015).

Od końca lat dziewięćdziesiątych do roku 2007 monitorowano uszkodzenia bulw ziemniaka spowodowane przez szkodniki glebowe. Do roku 2003 informacje o szkodach wyrządzonych przez drutowce, pędraki i rolnice nadsyłano niemal z całego kraju. Średnia wieloletnia $\mathrm{z}$ tego okresu wyniosła ponad $2 \%$ uszkodzonych bulw ziemniaka. Później nastąpił spadek obserwowanych uszkodzeń powodowanych przez szkodniki glebowe, utrzymujący się poniżej średniej z wielolecia (dla drutowców $2,1 \%$, pędraków $-1,9 \%$ i rolnic - 2,0\%). Ponownie zwiększoną liczebność tych szkodników obserwowano w roku 2006. Średnia liczba uszkodzonych bulw przez drutowce w tym okresie wynosiła $2,4 \%$. W województwie łódzkim, w Piotrkowie Trybunalskim odnotowano 8\% uszkodzonych bulw ziemniaka w czasie zbiorów. W roku 2006 najwięcej uszkodzonych bulw ziemniaka przez pędraki odnotowano w województwie pomorskim i mazowieckim - 5-5,5\%, a w Radomiu - 13,3\% i łódzkim $3,9 \%$, a w Piotrkowie Trybunalskim - 8\%. Jednak najwięcej w tym czasie zaobserwowano uszkodzeń spowodowanych przez gąsienice rolnic. Średnia liczba bulw uszkodzonych wynosiła 6,6\%. Najwięcej uszkodzonych bulw stwierdzono w południowo-centralnej Polsce, od 10,5\% do 13,2\% (Walczak i wsp. 2006, 2008). W ostatnich latach w wielu rejonach kraju notowane jest duże zagrożenie upraw ziemniaka przez drutowce i pędraki. Przyczyn zwiększonego występowania szkodników jest kilka, do najważniejszych z nich należą: błędy agrotechniczne, oszczędna uprawa płużna, zmiany klimatyczne oraz nieprawidłowe płodozmiany $\mathrm{w}$ przewadze zbóż i kukurydzy, które są dobrym siedliskiem tych szkodników. Uprawie nie sprzyjają także ograniczone możliwości zwalczania szkodników (drutowców, pędraków i rolnic), ponieważ na przestrzeni lat nastąpiło bardzo duże zawężenie $\mathrm{w}$ obrębie listy preparatów chemicznych do zwalczania szkodników glebowych (wycofywanie i usuwanie grup środków ochrony roślin). Do ochrony chemicznej na wiosnę, obecnie zarejestrowana jest jedna zaprawa insektycydowo-fungicydowa na drutowce $\mathrm{z}$ substancją czynną - imidachloprydem, należąca do grupy neonikotynoidów (Erlichowski 2016).
Pomimo występowania tak wielu agrofagów mogących ograniczać wytworzenie plonu dobrej jakości, przez wielolecia najbardziej dynamicznie rozwinęła się ochrona przed stonką ziemniaczaną. Rozwój prac badawczych nad insektycydami do zwalczania stonki ma szczególne znaczenie $\mathrm{w}$ ochronie roślin. Pierwsze metody zwalczania stonki były pracochłonne i polegały na jej zbieraniu, a następnie mechanicznym niszczeniu. Działanie takie było możliwe, ponieważ obowiązywała ustawa o ochronie roślin, z dnia 19 listopada 1956 r., w której nakazywano zwalczanie stonki pod groźbą grzywny lub aresztu (Węgorek 1959). Następnym etapem było już stosowanie środków chemicznych. Od stosowanych w latach 60. XX wieku pierwszych insektycydów $\mathrm{z}$ grupy węglowodorów chloroorganicznych, poprzez kolejne środki z nowych grup chemicznych wprowadzone do stosowania $\mathrm{w}$ latach: 80. XX wieku - pyretroidy i nereistoksyna; 90. XX wieku - pochodne benzoilomocznika i bakterie oraz w 2000 roku - neonikotynoidy i fenylopirazole (Pawińska i Mrówczyński 2000; Węgorek i wsp. 2003; Pawińska 2007, 2009; Sobczak 2013) (tab. 2). Kierunek zmian, jaki obserwuje się obecnie w zwalczaniu stonki pokazuje, że nowe insektycydy są bezpieczniejsze dla ludzi i środowiska, poprzez zmniejszenie dawki substancji czynnych, od $1200 \mathrm{~g} / \mathrm{ha}$ węglowodorów chloroorganicznych do $20-40 \mathrm{~g} / \mathrm{ha} \mathrm{w}$ nowych generacjach: pyretroidach, pochodnych benzoilomocznika, neonikotynoidach, fenylopirazolach, karboksamidach, fosforoorganicznych i antronilowanych diamidach (Pawińska i Mrówczyński 2000; Pawińska 2007) (tab. 3). W ostatnich latach z powodzeniem wykorzystuje się spinosad (substancja czynna) - neurotoksynę do zwalczania stonki ziemniaczanej z grupy makrocyklicznych laktonów, której działaniem jest obniżenie aktywności katalitycznej enzymu acetylocholinoesterazy (Sobczak 2013). W zależności od sposobu przemieszczania w chronionej roślinie, aktualnie zalecane neurotoksyny charakteryzują się działaniem kontaktowym, wgłębnym i systemicznym (układowym), a stosowane są głównie w formie zabiegu nalistnego.

Bardzo ważnym kierunkiem badań nad zwalczaniem stonki jest poszukiwanie biologicznych metod eliminacji szkodnika. W Polsce doświadczenia takie podjęto już w latach pięćdziesiątych poprzez introdukcje z Kanady zbrojca dwuplamego (Perillus bioculatus Fabr.). W następnych latach introdukowano inny gatunek drapieżnego pluskwiaka Podisus maculicentris Say, a także pasożyta Doryphorophaga doryphorae (Riley). Od lat sześćdziesiątych podjęto także badania nad możliwością wykorzystania grzybów entomopatogenicznych do zwalczania stonki (Pawińska i Mrówczyński 2000; Sosnowska i wsp. 2009).

Na podstawie danych z lat 1977-2006 stwierdzono, że nie było istotnego zróżnicowania $\mathrm{w}$ ochronie przed stonką ziemniaczaną, zarówno w liczbie zabiegów (od 1,2 do 1,5), jak i chronionej powierzchni (od 72 do 82\%) uprawy ziemniaka w Polsce (Pawińska 2009). Ostatnie badania zużycia środków ochrony roślin $\mathrm{w}$ uprawie ziemniaka (insektycydy) przeprowadzone w 2012 roku wykazały liczbę zabiegów od 1,0 do 2,0. Jeśli chodzi o chronioną powierzchnię upraw ziemniaka $\mathrm{w}$ Polsce preparatami przeciwko szkodnikom to stanowiła ona od 18,2 do $65,9 \%$ (tab. 4-6). Obecnie zarejestrowanych do zwalczania stonki ziemniaczanej w Polsce jest 58 insektycydów z 9 grup che- 
micznych. Zarejestrowane środki zawierają 17 różnych substancji czynnych (tab. 5-6) (MRiRW 2013). Substancje czynne reprezentują 8 różnych mechanizmów działania.
W Polsce odporność stonki ziemniaczanej w największym nasileniu stwierdzono w przypadku preparatu, zawierającego substancję czynną - chlorfenwinfos z grupy insek-

Tabela 2. Grupy chemiczne insektycydów stosowanych w ochronie ziemniaka w latach 1967-2017

Table 2. Chemical groups of insecticides used in potato protection in the years 1967-2017

\begin{tabular}{|c|c|c|c|c|c|c|c|c|c|c|c|c|c|}
\hline \multirow{2}{*}{$\begin{array}{c}\text { Nazwa grupy } \\
\text { chemicznej } \\
\text { Name } \\
\text { of chemical group }\end{array}$} & \multicolumn{13}{|c|}{ Lata - Years } \\
\hline & 1967 & 1969 & 1979 & 1987 & 1993 & 1999 & 2000 & 2006 & 2010 & 2012 & 2014 & 2016 & 2017 \\
\hline $\begin{array}{l}\text { Węglowodory } \\
\text { chloroorganiczne } \\
\text { Chloro-organic } \\
\text { hydrocarbons }\end{array}$ & $\mathrm{x}$ & $\mathrm{x}$ & $\mathrm{x}$ & $\mathrm{x}$ & $\mathrm{x}$ & - & - & - & - & - & - & - & - \\
\hline $\begin{array}{l}\text { Fosforoorganiczne } \\
\text { Organophorphorus }\end{array}$ & - & - & $\mathrm{x}$ & $\mathrm{x}$ & $\mathrm{x}$ & $\mathrm{x}$ & $\mathrm{x}$ & $\mathrm{x}$ & $\mathrm{x}$ & $\mathrm{x}$ & $\mathrm{x}$ & $\mathrm{x}$ & $\mathrm{x}$ \\
\hline $\begin{array}{l}\text { Karbaminiany } \\
\text { Carbomates }\end{array}$ & - & - & $\mathrm{x}$ & $\mathrm{x}$ & $\mathrm{x}$ & $\mathrm{x}$ & $\mathrm{x}$ & $\mathrm{x}$ & $\mathrm{x}$ & $\mathrm{x}$ & $\mathrm{x}$ & - & - \\
\hline $\begin{array}{l}\text { Pyretroidy } \\
\text { Pyrethroids }\end{array}$ & - & - & - & $\mathrm{x}$ & $\mathrm{x}$ & $\mathrm{x}$ & $\mathrm{x}$ & $\mathrm{x}$ & $\mathrm{x}$ & $\mathrm{x}$ & $\mathrm{x}$ & $\mathrm{x}$ & $\mathrm{x}$ \\
\hline $\begin{array}{l}\text { Nereistoksyny } \\
\text { Nereistoxin }\end{array}$ & - & - & - & $\mathrm{x}$ & $\mathrm{x}$ & $\mathrm{x}$ & $\mathrm{x}$ & $\mathrm{x}$ & - & - & - & - & - \\
\hline $\begin{array}{l}\text { Pochodne } \\
\text { benzoilomocznika } \\
\text { Benzoylurea } \\
\text { derivatives }\end{array}$ & - & - & - & - & $\mathrm{x}$ & $\mathrm{x}$ & $\mathrm{x}$ & $\mathrm{x}$ & - & - & - & - & - \\
\hline $\begin{array}{l}\text { Bakterie } \\
\text { Bacteria }\end{array}$ & - & - & - & - & $\mathrm{x}$ & $\mathrm{x}$ & $\mathrm{x}$ & - & - & - & - & - & - \\
\hline $\begin{array}{l}\text { Neonikotynoidy } \\
\text { Neonicotinoids }\end{array}$ & - & - & - & - & - & $\mathrm{x}$ & $\mathrm{x}$ & $\mathrm{x}$ & $\mathrm{x}$ & $\mathrm{x}$ & $\mathrm{x}$ & $\mathrm{x}$ & $\mathrm{x}$ \\
\hline $\begin{array}{l}\text { Fenylopirazole } \\
\text { Phenylopyrazoles }\end{array}$ & - & - & - & - & - & $\mathrm{x}$ & $\mathrm{x}$ & $\mathrm{x}$ & $\mathrm{x}$ & $\mathrm{x}$ & $\mathrm{X}$ & - & - \\
\hline $\begin{array}{l}\text { Karboksamidy } \\
\text { Carboxamides }\end{array}$ & - & - & - & - & - & - & - & - & $\mathrm{X}$ & $\mathrm{x}$ & $\mathrm{X}$ & $\mathrm{x}$ & $\mathrm{X}$ \\
\hline $\begin{array}{l}\text { Antronilowane } \\
\text { diamidy } \\
\text { Antronilated } \\
\text { diamides } \\
\end{array}$ & - & - & - & - & - & - & - & - & - & $\mathrm{x}$ & $\mathrm{X}$ & $\mathrm{x}$ & $\mathrm{X}$ \\
\hline $\begin{array}{l}\text { Makrocykliczne } \\
\text { laktony } \\
\text { Macrocyclic } \\
\text { lactones }\end{array}$ & - & - & - & - & - & - & - & - & - & $\mathrm{x}$ & $\mathrm{x}$ & $\mathrm{x}$ & $\mathrm{x}$ \\
\hline
\end{tabular}

Według Pawińskiej (2007), opracowanie własne na podstawie Zaleceń IOR - PIB Mrówczyński

According to Pawińska (2007), own elaboration based on IPP - NRI recommendations Mrówczyński

Tabela 3. Zmiany w zakresie stosowanych insektycydów w uprawach ziemniaka w latach 1960-2017

Table 3. Changes in the use of insecticides in potato crops in the years 1960-2017

\begin{tabular}{l|c|c|c|c|c|c|c}
\hline \multicolumn{1}{c|}{\begin{tabular}{c}
\multicolumn{7}{c}{ Charakterystyka } \\
\multicolumn{1}{c|}{ Characteristic }
\end{tabular}} & \multicolumn{7}{c}{ Lata - Years } \\
\cline { 2 - 8 } & $1960-1980$ & $1981-1990$ & $1991-2000$ & $2001-2006$ & $2007-2010$ & $2011-2016$ & 2017 \\
\hline $\begin{array}{l}\text { Liczba insektycydów } \\
\text { Number of insecticides }\end{array}$ & 22 & 37 & 35 & 41 & 34 & 43 & 55 \\
\hline $\begin{array}{l}\text { Liczba substancji czynnych } \\
\text { Number of active substances }\end{array}$ & 21 & 36 & 28 & 24 & 21 & 23 & 16 \\
\hline $\begin{array}{l}\text { Średnia dawka substancji czynnych } \\
\begin{array}{l}\text { Average dose of active substances } \\
\text { [g/ha] }\end{array}\end{array}$ & 800 & 300 & 160 & 150 & 130 & 90 & 71 \\
\hline
\end{tabular}

Według Pawińskiej (2007), opracowanie własne na podstawie Zaleceń IOR - PIB Mrówczyński

According to Pawińska (2007), own elaboration based on IPP - NRI recommendations Mrówczyński 
Tabela 4. Zakres ochrony ziemniaka przed stonką ziemniaczaną w latach 1977-2006

Table 4. The scope of protection against Colorado potato beetle in the years 1977-2006

\begin{tabular}{c|c|c|c|c|c|c|c|c}
\hline \multirow{2}{*}{$\begin{array}{c}\text { Zwalczane agrofagi } \\
\text { Controlled pests }\end{array}$} & \multicolumn{4}{|c|}{$\begin{array}{c}\text { Liczba zabiegów } \\
\text { Number of chemical treatments }\end{array}$} & \multicolumn{3}{c}{ Powierzchnia chroniona - Protected area } \\
\cline { 2 - 9 } & $1977-1980$ & $1981-1991$ & $1991-2000$ & $2001-2006$ & $1977-1980$ & $1981-1991$ & $1991-2000$ & $2001-2006$ \\
\hline $\begin{array}{l}\text { Stonka ziemniaczana } \\
\text { Colorado potato beetle }\end{array}$ & 1,2 & 1,2 & 1,5 & 1,5 & 74,5 & 75,9 & 81,5 & 72,0 \\
\hline
\end{tabular}

Według Pawińskiej (2009) - According to Pawińska (2009)

Tabela 5. Zużycie insektycydów do ochrony ziemniaka przed szkodnikami w roku 2012

Table 5. Consumption of insecticides to protect against pests of potato in 2012

\begin{tabular}{l|c|c}
\hline \multicolumn{1}{c|}{$\begin{array}{c}\text { Substancja czynna } \\
\text { Active substance }\end{array}$} & $\begin{array}{c}\text { Liczba zabiegów } \\
\text { Number of chemical treatments }\end{array}$ & $\begin{array}{c}\text { Powierzchnia chroniona } \\
\text { Protected area } \\
\text { [\%] }\end{array}$ \\
\hline Alfa-cypermetryna - Alpha-cypermethrin & 1,00 & 2,16 \\
\hline Beta-cyflutryna - Beta-cyfluthrin & 1,00 & 0,48 \\
\hline Cypermetryna - Cypermethrin & 1,00 & 0,21 \\
\hline Deltametryna - Deltamethrin & 1,15 & 7,75 \\
\hline Esfenwalerat - Esfenvalerate & 1,19 & 0,43 \\
\hline Gamma-cyhalotryna - Gamma-cyhalothrin & 1,00 & 0,12 \\
\hline Lambda-cyhalotryna - Lambda-cyhalothrin & 1,23 & 6,33 \\
\hline Zeta-cypermetryna - Zeta-cypermethrin & 1,12 & 0,76 \\
\hline Oksamyl - Oxamyl & 1,00 & 0,03 \\
\hline Pirymikarb - Pirimicarb & 2,00 & 0,10 \\
\hline Chlotianidyna - Clothianidin & 1,16 & 22,88 \\
\hline Tiametoksam - Thiamethoxam & 1,09 & 27,13 \\
\hline Flonikamid - Flonicamid & 1,64 & 0,05 \\
\hline Acetamipryd - Acetamiprid & 1,06 & 2,85 \\
\hline Imidachlopryd - Imidacloprid & 1,01 & 8,45 \\
\hline Tiachlopryd - Thiacloprid & 1,08 & 4,61 \\
\hline Metaflumizon - Metaflumizone & 1,01 & 2,20 \\
\hline Teto & & \\
\hline
\end{tabular}

Według Stobieckiego (2012) - According to Stobiecki (2012)

Tabela 6. Liczba insektycydów należących do różnych grup chemicznych zarejestrowanych w Polsce w latach 2005-2017 do zwalczania stonki ziemniaczane

Table 6. Number of insecticides from different chemical groups registered to control Colorado potato beetle in Poland in the years 2005-2017

\begin{tabular}{l|c|c|c}
\hline \multicolumn{1}{c}{$\begin{array}{c}\text { Grupy chemiczne } \\
\text { Number of chemical groups }\end{array}$} & \multicolumn{2}{c}{ Lata - Years } & 2017 \\
\cline { 2 - 4 } & \multicolumn{1}{c|}{1} & 2005 & 4 \\
\hline Chloronikotynyle - Chloronicotinyl & 2 & 5 & 3 \\
\hline Fosforoorganiczne - Organophosphorus & 6 & - & 1 \\
\hline Karbaminiany - Carbamates & 5 & - & - \\
\hline Pyretroidy - Pyrethroids & 24 & - & 32 \\
\hline Nereistoksyny - Nereistoxin & 2 & 15 & - \\
\hline Pochodne benzoilomocznika & 1 & - & 1 \\
Derivative of benzoylurea & - & 4 & 12 \\
\hline Bakterie - Bacteria & 3 & - & - \\
\hline Neonikotynoidy - Neonicotinoids & 1 & & \\
\hline Fenylopirazole - Phenylpyrazoles & & & \\
\hline
\end{tabular}




\begin{tabular}{|c|c|c|c|}
\hline 1 & 2 & 3 & 4 \\
\hline Karbonylohydrazydy - Carbonyl hydrazides & - & 1 & - \\
\hline Antronilowane diamidy - Antronilated diamides & - & - & 1 \\
\hline Makrocykliczne laktony - Macrocyclic lactones & - & - & 1 \\
\hline $\begin{array}{l}\text { Pyretroidy + chloronikotynyle } \\
\text { Pyrethroid + chloronicotinol }\end{array}$ & - & 1 & 1 \\
\hline $\begin{array}{l}\text { Pyretroidy + fosforoorganiczne } \\
\text { Pyrethroid + organophosphorus }\end{array}$ & 3 & 1 & 6 \\
\hline Razem - Total & 48 & 28 & 58 \\
\hline
\end{tabular}

tycydów fosforoorganicznych. Wcześniej, choć na mniejszą skalę, stwierdzono również odporność w odniesieniu do insektycydów chloroorganicznych: DDT, lindanu, metoksychloru oraz karbaminianów: karbarylu i propoksuru. W dalszej kolejności stwierdzono odporność na insektycydy z grupy pyretroidów oraz pochodną nereistoksyny bensultap (Węgorek i wsp. 2003). Wyniki prac prowadzonych kilka lat później potwierdzają utrzymującą się odporność stonki ziemniaczanej na związki fosforoorganiczne (chloropiryfos) (Zamojska i wsp. 2010). Słaby poziom wrażliwości szkodnika na chloropiryfos stwierdzono podczas badań prowadzonych w latach 2008-2010, a jednocześnie nie stwierdzono odporności stonki ziemniaczanej na acetamipryd z grupy neonikotynoidów (Węgorek i wsp. 2011). W ostatnich latach obserwowany jest w Polsce spadek odporności stonki ziemniaczanej na pyretroidy, co może być spowodowane stosowaniem na dużą skalę środków zawierających substancje czynne z grupy neonikotynoidów oraz substancji fipronil należącej do fenylopirazoli oraz mniejszą zdolnością adaptacyjną osobników odpornych (Zamojska i wsp. 2010). Warto jednak zaznaczyć, że od 2007 roku nie ma już w Polsce zarejestrowanych środków ochrony roślin zawierających fipronil (Sobczak 2013).

Arthropod Pesticide Resistance Database (2013) na podstawie danych z różnych krajów opisuje przypadki uodparniania się stonki ziemniaczanej na różne substancje insektycydowe z grup: fosforoorganicznych, pyretroidów, neonikotynoidów, preparatów biologicznych i makrocyklicznych laktonów (Sobczak 2013).

Tak dużych sukcesów, jak w ochronie przed stonką ziemniaczaną nie odnotowano w przypadku innych agrofagów. Obecnie nie ma preparatów do ochrony przed chorobami wirusowymi, a wprowadzone od lat 80 . XX wieku i obecnie aficydy do zwalczania mszyc na plantacjach nasiennych wykazują najlepszą skuteczność, gdy zastosowane są w odmianach o podwyższonej odporności na wirusy (Pawińska 2009). Zakres stosowania ośmiu środków obejmuje ochronę ziemniaka przed mszycami. Są to środki o działaniu powierzchniowym w roślinie, zawierające substancję z grupy pyretroidów, środki o działaniu systemicznym zawierające substancje z grup: karboksamidów (1), karbaminianów (2 środki przeznaczone jedynie do ochrony plantacji nasiennych ziemniaka) oraz neonikotynoidów (1 zaprawa) (Sobczak 2013). Zgodnie z danymi Arthropod Pesticide Resistance Database (2013) na świecie odnotowano przypadki uodparniania się mszycy brzoskwiniowo-ziemniaczanej w różnych uprawach m.in. na substancje z grupy karbaminianów, neonikotynoidów i pyretroidów. W Polsce prowadzone są badania nad odpornością mszyc, ponieważ zjawisko to nie było dotąd w naszym kraju badane (Węgorek i wsp. 2011).

Próby ograniczania populacji mątwików preparatami chemicznymi także nie przynoszą spodziewanych efektów, a podstawową metodą jest izolacja pól oraz odmiany odporne i dobra agrotechnika. Natomiast narastający problem szkodników glebowych (pędraków, drutowców i gąsienic rolnic) rozwiązuje się obecnie metodami agrotechnicznymi, w tym przez zaprawianie sadzeniaków dwuskładnikową zaprawą zawierającą imidachlopryd i pencykuron (Erlichowski i wsp. 1998; Erlichowski 2016) oraz stosowaniem różnego rodzaju pułapek feromonowych czy przynętowych (Jakubowska i Bocianowski 2016).

\section{Podsumowanie / Summary}

Po wnikliwej analizie ekspansji szkodnika w Polsce, zdecydowanie można stwierdzić, że od kilku lat największe zagrożenie stwarza stonka ziemniaczana i będzie je stanowiła w makroregionach południowo-wschodniej i centralnej Polski z uwzględnieniem województw warmińsko-mazurskiego i częściowo kujawsko-pomorskiego. Natomiast $\mathrm{w}$ makroregionie nadmorskim zdecydowanie od paru lat utrwalił się niski poziom zagrożenia upraw ziemniaka ze strony stonki ziemniaczanej.

Największe zmiany w ochronie ziemniaka przed szkodnikami odnotowano dla stonki ziemniaczanej. Przy tak dużej liczbie preparatów chemicznych stonka nie powinna być szkodnikiem mającym istotne znaczenie gospodarcze. Jest agrofagiem, który może być stosunkowo łatwo utrzymany na poziomie niepowodującym strat ekonomicznych, pod warunkiem ścisłego przestrzegania podstawowych zasad zwalczania.

W Polsce, podobnie jak i w innych krajach, gdzie uprawiany jest ziemniak na znacznym areale, na skutek ciągłego zwalczania stonki istnieje ryzyko wytwarzania się ras odpornych owada na stosowane insektycydy.

Obecnie nie ma skutecznych metod zwalczania mszyc na ziemniaku. Próby ograniczenia populacji mątwików preparatami chemicznymi także nie przynoszą spodziewanych efektów, a podstawową metodą jest izolacja pól oraz odmiany odporne i dobra agrotechnika. Ochrona przed szkodnikami glebowymi ogranicza się do metody agrotechnicznej oraz zaprawiania sadzeniaków. 


\section{Literatura / References}

Arthropod Pesticide Resistance Database 2013. http://www.pesticideresistance.com/search.php [Accessed: 02.07.2013].

Dzwonkowski W. 2008. Rynek skrobi ziemniaka w Polsce i w Unii Europejskiej. IERiGŻ - PIB. http://www.minrol.gov.pl/pol/content/ /download/21047/110833/file/ekspertyza_kwoty [dostęp: 23.04.2017].

Erlichowski T. 2016. Szkodniki glebowe w uprawie ziemniaka. http://www.wrp.pl/szkodniki-glebowe-w-uprawie-ziemniak/ [dostęp: 13.04.2017].

Erlichowski T., Robak B. 2016. Dynamika liczebności i presja mszyc, wektorów wirusów, w uprawach ziemniaka w Polsce w 2016 r. Ziemniak Polski 4: 4-10.

Erlichowski T., Urbanowicz J., Pawińska M. 1998. Metody aplikacji a skuteczność działania zaprawy fungicydowo-insektycydowej w uprawie ziemniaka. [Methods of application and efficacy fungicide and insecticide seed dressing]. Progress in Plant Protection/ /Postępy w Ochronie Roślin 38 (2): 512-514.

Jakubowska M., Bocianowski J. 2016. Ocena pułapek feromonowych zawierających estry geranylu stosowanych do monitorowania chrząszczy z rodziny Elateridae w uprawach. [Evaluation of the geranyl esters-containing pheromone traps used for monitoring Elateridae family beetles in crops]. Przemysł Chemiczny 95 (9): 1698-1704. DOI:10.15199/62.2016.9.8.

Kostiw M. 2007. Apis frangulae Kaltenbach, 1845 on potato crop in 1970-2005 and the ongoing changes. [Występowanie mszycy kruszynowo-ziemniaczanej (Apis frangulae Kalt.) w uprawie ziemniaka w latach 1970-2005 i zachodzące zmiany]. Aphids and other Hemipterous Insects 13: 91-98.

Kostiw M. 2011. Epidemiologia chorób wirusowych ziemniaka w świetle aktualnych uwarunkowań przyrodniczych i biologicznych. Materiały Konferencji Naukowo-Szkoleniowej „Nasiennictwo i ochrona ziemniaka”. Darłówko, 19-20.05.2011, IHAR Bonin: 17-20.

Kostiw M., Robak B. 2008. Skład gatunkowy, termin migracji i dynamika liczebności mszyc „nieziemniaczanych” w uprawie ziemniaka $w$ różnych rejonach kraju. [Species composition, migration period and dynamics of number of non potato colonizing aphids in different regions of Poland]. Progress in Plant Protection/Postępy w Ochronie Roślin 48 (3): 881-888.

Kostiw M., Robak B. 2009. Występowanie mszyc Myzus persicae (Sulz.) i Aphis nasturtii Kalt. w uprawach ziemniaka w różnych rejonach kraju. [The occurrence of aphids Myzus persicae (Sulz.) and Aphis nasturtii Kalt. in potato crop in differend region of Poland]. Progress in Plant Protection/Postępy w Ochronie Roślin 49 (3): 1187-1191.

Kostiw M., Robak B. 2010. Presja wirusów Y, M, S i liściozwoju ziemniaka w latach 2006-2009 w Boninie. [Infection pressure of PVY, PVM, PVS and PLRV in the period 2006-2008 in Bonin]. Biuletyn Instytutu Hodowli i Aklimatyzacji Roślin 256: 141-151.

Kostiw M., Robak B. 2012. Dynamika liczebności mszyc, wektorów wirusów, w latach 2010-2012 i zagrożenie plantacji nasiennych ziemniaka przez wirusy Y i liściozwoju w 2012 r. Ziemniak Polski 4: 18-23.

Kostiw M., Robak B. 2013. Presja mszyc w 2013 roku i zagrożenie plantacji nasiennych ziemniaka wirusami Y i liściozwoju. Ziemniak Polski 4: 8-13.

Ministerstwo Rolnictwa i Rozwoju Wsi 2013. Rejestracja insektycydów, herbicydów oraz fungicydów stosowanych w ochronie ziemniaka (wyszukiwarka). http://www.minrol.gov.pl/pol/Informacje-branzowe/Wyszukiwarka-srodkow-ochrony-roslin [dostęp: 02.07.2017].

Nowacki W. 2009. Stan aktualny i perspektywy produkcji ziemniaka w Polsce do 2020 roku. Studia i Raporty IUNG - PIB 14: 71-94.

Nowacki W. 2012. O kierunkach zmian w uprawie ziemniaka w Polsce. [On the directions of changes in potato production in Poland]. Biuletyn Instytutu Hodowli i Aklimatyzacji Roślin 266: 21-35.

Pawińska M. 1995. The occurrence and control of the Colorado potato beetle (Leptinotarsa decemlineata Say), under Polish conditions in period 1983-1993. Insect-chemical, physiological and environmental aspects. Wydawnictwo Uniwersytetu Wrockawskiego, Wrocław: $329-332$.

Pawińska M. 2007. Skuteczność insektycydów nowej generacji w zwalczaniu stonki ziemniaczanej Leptinotarsa decemlineata Say. [Efficacy of new generation insecticides in Colorado potato beetle control]. Progress in Plant Protection/Postepy w Ochronie Roślin 47 (1): 340-347.

Pawińska M. 2009. Historia i kierunki ochrony plantacji ziemniaka przed głównymi agrofagami. [History and directions of potato protection against harmful agrophages]. Progress in Plant Protection/Postępy w Ochronie Roślin 49 (4): 1637-1642.

Pawińska M., Mrówczyński M. 2000. Występowanie i zwalczanie stonki ziemniaczanej (Leptinotarsa decemlineata Say) w latach 1978-1999. [Occurrence and control of Colorado potato beetle in 1978-1999]. Progress in Plant Protection/Postępy w Ochronie Roślin 40 (1): 292-299.

Piekarczyk K., Pruszyński S., Matysiak M. 1984. Masowy pojaw stonki ziemniaczanej (Leptinotarsa decemlineata Say) w 1983 roku, jej zwalczanie i prognoza pojawu w roku 1984. Materiały 24. Sesji Naukowej Instytutu Ochrony Roślin: 229-242.

Pospieszny H., Borodynko N., Hasiów-Jaroszewska B. 2009. Wirus Y ziemniaka (Potato virus Y, PVY) na pomidorze szklarniowym. [Potato virus Y (PVY) on the greenhouse tomato]. Progress in Plant Protection/Postępy w Ochronie Roślin 49 (3): 1327-1330.

Rynek ziemniaka oraz stan i perspektywy Nr 1-36. Wydawnictwo IERiGŻ, ARR, MRiGŻ. Analizy rynkowe z lat 1990-2011.

Sobczak J. 2013. Możliwości rotacji środków ochrony roślin w strategii zapobiegania uodporniania się agrofagów ziemniaka. [Possibilities of plant protection products rotation in strategy against spreading of resistance amongst potato pests]. Biuletyn Instytutu Hodowli i Aklimatyzacji Roślin 269: 87-100.

Sosnowska D., Pruszyński S., Lipa J.J. 2009. Ewolucja metod i środków w zwalczaniu stonki ziemniaczanej (Leptinotarsa decemlineata Say). [Development of methods and insecticides for control of Colorado potato beetle (Leptinotarsa decemlineata Say)]. Progress in Plant Protection/Postepy w Ochronie Roślin 49 (2): 565-576.

Tratwal A., Jakubowska M., Roik K., Wielkopolan B. 2016. Stan fitosanitarny roślin uprawnych w Polsce w roku 2015 i spodziewane wystapienie agrofagów w 2016. Instytut Ochrony Roślin - Państwowy Instytut Badawczy, Poznań, 123 ss.

Walczak F., Gałęzewski M., Jakubowska M., Skorupska A., Tratwal A., Wójtowicz A., Złotkowski J. 2006. Stan fitosanitarny roślin uprawnych w Polsce w roku 2006 i spodziewane wystąpienie agrofagów w roku 2007. Instytut Ochrony Roślin - Państwowy Instytut Badawczy, Poznań, 96 ss.

Walczak F., Gałęzewski M., Jakubowska M., Skorupska A., Tratwal A., Wójtowicz A., Złotkowski J. 2008. Stan fitosanitarny roślin uprawnych w Polsce w roku 2007 i spodziewane wystąpienie agrofagów w roku 2008. Instytut Ochrony Roślin - Państwowy Instytut Badawczy, Poznań, 108 ss. 
Węgorek W. 1959. Stonka ziemniaczana (Leptinotarsa decemlineata Say). Prace Naukowe Instytutu Ochrony Roślin 2 (1): 7-178.

Węgorek P., Mrówczyński M., Wachowiak H., Pawińska M., Przybysz E. 2003. Strategia chemicznego zwalczania stonki ziemniaczanej (Leptinotarsa decemlineata Say) w Polsce. Instrukcja wdrożeniowa. Instytut Ochrony Roślin, Poznań, 28 ss. ISBN 83-916204-6-8.

Węgorek P., Zamojska J., Mrówczyński M. 2011. Susceptibility level of the Colorado potato beetle (Leptinotarsa decemlineata Say) to chlorpyrifos and acetamiprid in Poland and resistance mechanisms of the pest to chlorpyrifos. [Poziom wrażliwości stonki ziemniaczanej (Leptinotarsa decemlineata Say) na chloropiryfos i acetamipryd w Polsce oraz mechanizmy odporności szkodnika na chloropiryfos]. Journal of Plant Protection Research 51 (3): 279-284. DOI: https://doi.org/10.2478/v10045-011-0046-4.

Wróbel S. 2015. The rate of virus spread in new potato cultivars in the north of Poland. Potato Research 58 (4): $329-342$. DOI: https://doi.org/10.1007/s11540-015-9308-2.

Wróbel S., Robak B. 2015. Presja mszyc w Polsce w roku 2015. Ziemniak Polski 4: 12-17.

Zamojska J., Węgorek P., Mrówczyński M. 2010. Obecny poziom odporności na insektycydy dla wybranych gatunków owadów w Polsce. [Current status of a threat by resistance to insecticides of selected insect species in Poland]. Progress in Plant Protection/Postępy w Ochronie Roślin 50 (3): 1205-1212. 